\title{
PENERAPAN MODEL PROBLEM BASED INSTRUCTION \\ UNTUK MENINGKATKAN HASIL BELAJAR MAHASISWA \\ PADA MATA KULIAH EKONOMI PEMBANGUNAN
}

\section{Tiara Anggia Dewi \\ Program Studi Pendidikan Ekonomi FKIP Universitas Muhammadiyah Metro \\ E-mail: tiara.anggia09@gmail.com}

\begin{abstract}
Abstrak
Tujuan penelitian ini adalah untuk mengetahui pengaruh penerapan model Problem Based Instruction (PBI) untuk meningkatkan hasil belajar mahasiswa pada matakuliah Ekonomi Pembangunan. Metode yang digunakan dalam penelitian ini eksperimen design yaitu pretest posttest control group design.Analisis data menunjukkan hasil belajar model Problem Based Instruction mengalami peningkatan 51,5\% dilihat dari perbandingan evaluasi pretestmahasiswa $28,5 \%$ sedangkan mahasiswa yang mencapai kriteria ketuntasan minimal pada evaluasi posttest adalah $80 \%$.Berdasarkan hasil penelitian tersebut maka hipotesis dapat diterima sebab $t_{\text {hitung }}\left(t_{\text {daf }}\right)=3,76$ lebih besar dari pada $t_{\text {tabel }}\left(t_{\text {tab }}\right)=1,70$ dan 2,47. Dengan demikian menunjukkan bahwa penerapan model Problem Based Instruction pada matakuliah Ekonomi Pembangunan dapat meningkatkan hasil belajar mahasiswa di UM Metro Kata kunci:Model Problem Based Instruction, Hasil Belajar
\end{abstract}

\section{PENDAHULUAN}

Kualitas pembelajaran pada suatu institusi pendidikan merupakan faktor yang sangat penting dalam mencetak lulusan yang bermutu. Apabila proses dan produknya baik, maka dapat dikatakan bahwa kualitas pembelajaran juga baik. Proses pembelajaran merupakan rangkaian kegiatan komunikasi antara peserta didik yang belajar dengan pendidik. Proses pembelajaran akan lebih efektif jika dikelola secara optimal. Dari segi proses pembelajaran dikatakan berhasil dan berkualitas apabila setidaknya $75 \%$ peserta didik terlibat secara aktif dalam proses pembelajaran. Dari segi hasil, seorang peserta didik dipandang tuntas belajar jika mampu menguasai konsep setidaknya $65 \%$ dari seluruh tujuan pembelajaran minimal sedangkan keberhasilan klasikal dicapai jika sekurang-kurangnya $85 \%$ dari seluruh peserta didik tuntas belajar (Mulyasa 2006).

Salah satu aspek yang berperan sangat luar biasa dalam keberhasilan proses pembelajaran adalah metode pengajaran (learning methods - models of instructions). Aspek tersebut mendukung keberhasilan proses penyampaian materi pembelajaran (learning contents) di dalam kelas sesuai tujuan pembelajaran (learning objectives). Dosen dituntut menguasai berbagai macam metode pembelajaran yang sesuai dengan karakteristik materi 
dan peserta didik. Dalam memilih metode pembelajaran, keaktifan peserta didik harus diperhatikan dengan baik, karena keberhasilan pembelajaran tidak hanya terletak pada hasil tetapi juga dari proses dalam pembelajaran.

Namun dalam pelaksanaannya, pembelajaran pada mata kuliah ekonomi pembangunan di program studi Pendidikan Ekonomi UM Metro dari sisi teknik pengajarannya masih kurang sistematis, sehingga daya serap mahasiswa rendah. Penyampaian materi kuliah lebih bersifat monoton, mahamahasiswa kurang dituntut untuk aktif dalam proses pembelajaran di kelas. Dari pihak dosen metode penyampaian materi masih bersifat ceramah. Dampaknya adalah rendahnya penguasaan konsep dan keterampilan mahamahasiswa terhadap matakuliah ekonomi pembangunan.

Berkaitan dengan hal tersebut, dalam pembelajaran matakuliah ekonomi pembangunan diperlukan suatu model pembelajaran yang berkenaan langsung dengan permasalahan di lapangan. Dengan demikian mahasiswa akan terdorong untuk aktif dalam pembelajaran, sehingga mahasiswa lebih mudah dalam memahami materi yang dipelajari dan pembelajaran berlangsung dalam komunikasi multi arah. Salah satu model pembelajaran yang cocok diterapkan dalam pembelajaran tersebut adalah model Problem Based Instruction yang dikenal dengan Problem Based Instruction atau PBI (Ibrahim, 2004).

Model pembelajaran Problem Based Instruction (PBI) merupakan model pembelajaran yang menggunakan suatu permasalahan di dalam kehidupan seharihari untuk diidentifikasi dan dipecahkan, tidak hanya terpusat pada penguasaan materi.Model pembelajaran Problem Based Instruction (PBI) mendorong mahasiswa untuk menganalisis masalah, mencari informasi, menyusun hipotesis, serta memecahkan suatu permasalahan. Kelebihan model pembelajaran PBI mampu meningkatkan motivasi mahasiswa dalam pembelajaran, mendorong kerjasama dalam menyelesaikan masalah, mendorong mahasiswa melakukan pengamatan dan dialog dengan orang lain, melibatkan mahasiswa dalam penyelidikan pilihan sendiri.Hal ini memungkinkan mahasiswa untuk menjelaskan serta membangun pemahamannya sendiri mengenai fenomena tersebut.

Problem Based Instruction merupakan pembelajaran dengan pendekatan konstruktivis, yang mengatakan bahwa pengetahuan tidak statis, tetapi berevolusi dan berubah secara konstan selama pelajar mengonstruksikan pengalamanpengalaman baru yang memaksaka mereka untuk mendasarkan diri dan memodifikasi 
pengetahuan sebelumnya.Dosen berperan sebagai penyaji masalah, penanya, mengadakan dialog, pemberi fasifitas penelitian, menyiapkan dukungan dan dorongan yang dapat meningkatkan pertumbuhan inkuiri dan intelektual peserta didik.Prinsip utama pendekatan konstruktivis adalah pengetahuan tidak diterima secara pasif, tetapi dibangun secara aktif oleh individu (Nasution, 2008).

Berdasarkan uraian di atas akan dilakukan penelitian mengenai pengaruh penerapan model Problem Based Instruction (PBI) untuk meningkatkan hasil belajar mahasiswa pada matakuliah Ekonomi Pembangunan.

\section{KAJIAN PUSTAKA}

\section{Model Problem Based Instruction} (PBI)

Menurut Ibrahim (2004:2) Model pembelajaran PBI mempunyai beberapa nama lain seperti Project-based Teaching (belajar proyek), experienced-based Education (pembelajaran berdasar pengalaman), Authentic Learning (belajar autentik) dan Anchored Instruction (belajar berdasar kehidupan nyata). Model PBI adalah model pembelajaran yang menggunakan masalah kehidupan nyata sebagai konteks untuk belajar tentang cara berpikir kritis dan ketrampilan pemecahan masalah, serta untuk memperoleh pengetahuan dan konsep yang esensial dari materi pelajaran (Nurhadi 2004).

Menurut Dewey (Trianto, 2007: 67) belajar berdasarkan masalah adalah interaksi antara stimulus dengan respon, merupakan hubungan antara dua arah belajar dan lingkungan.Lingkungan memberi masukan kepada siswa berupa bantuan dan masalah, sedangkan sistem saraf otak berfungsi menafsikan bantuan itu secara efektif sehingga masalah yang dihadapi dapat diselidiki, dinilai, dianalisis, serta dicari pemecahannya dengan baik. Pengalaman siswa yang diperoleh dari lingkungan akan menjadikan kepadanya bahan dan materi guna memperoleh pengertian serta bisa dijadikan pedoman dan tujuan belajarnya.

Menurut Ibrahim dan Nur (2004) PBI mempunyai ciri-ciri dan tujuan sebagai berikut.

a. Ciri-ciri Model PBI antara lain :

1) Pengajuan pertanyaan atau masalah

2) Berfokus pada keterkaitan antar disiplin

3) Penyelidikan autentik

4) Menghasilkan produk / karya dan memamerkannya

5) Kerjasama

b. Tujuan Model PBI adalah :

1) Membantu mahasiswa mengembangkan kemampuan 
berpikir, pemecahan masalah, dan kemampuan intelektual.

2) Belajar berbagai peran orang dewasa melalui pelibataan mereka dalam pengalaman nyata atau simulasi.

3) Menjadi pebelajar yang otonom dan mandiri.

Model PBI terdiri dari lima tahap utama yang dimulai dengan guru memperkenalkan mahasiswapada situasi masalah dan diakhiri dengan penyajian dan analisis kerja siswa. Kelima tahap tersebut dapat diselesaikan dalam 1 pertemuan, 2 atau 3 kali pertemuan.Jika memungkinkan bahkan dapat juga dilaksanakan dalam satu semester/ satu tahun (Suparmanto 2004). Kelima tahapan tersebut dapat dilihat pada Tabel 1 dibawah ini:

\begin{tabular}{|l|l|}
\hline \multicolumn{1}{|c|}{ TAHAP } & \multicolumn{1}{c|}{ TINGKAH LAKU GURU } \\
\hline $\begin{array}{l}\text { Tahap 1: } \\
\text { Mengenalkan siswa pada }\end{array}$ & $\begin{array}{l}\text { Guru menjelaskan tujuan pelajaran,menjelaskan hal-hal } \\
\text { penting yang diperlukandan memotivasi siswa untuk } \\
\text { memilih sendirikegiatan pemecahan masalah. }\end{array}$ \\
$\begin{array}{l}\text { Tahap 2: } \\
\text { Mengorganisasi siswa } \\
\text { untuk belajar }\end{array}$ & $\begin{array}{l}\text {-Guru membantu siswa mendefinisikan danmengatur } \\
\text { tugas-tugas belajar yangberhubungan dengan masalah. }\end{array}$ \\
$\begin{array}{l}\text { Tahap 3: } \\
\text { Membantu penelitian } \\
\text { mandiri dan kelompok }\end{array}$ & $\begin{array}{l}\text { Guru mendorong siswa untuk membagiinformasi yang } \\
\text { sesuai, melaksanakaneksperimen dan mendapatkan } \\
\text { penjelasandan pemecahan masalah. }\end{array}$ \\
$\begin{array}{l}\text { Tahap 4: } \\
\text { Mengembangkan dan } \\
\text { menampilkan karya yang ada }\end{array}$ & $\begin{array}{l}\text { Guru membantu siswa untuk merencanakandan } \\
\text { menyiapkan karya yang sesuai sepertilaporan, video, } \\
\text { model serta membantumereka untuk bekerja sama dan } \\
\text { menjelaskankerjanya dengan yang lain. }\end{array}$ \\
$\begin{array}{l}\text { Tahap 5: } \\
\text { Analisis dan evaluasi } \\
\text { proses pemecahan } \\
\text { masalah }\end{array}$ & $\begin{array}{l}\text { Guru membantu siswa untuk melakukanrefleksi atau } \\
\text { evaluasi terhadap penelitianmereka dan proses yang } \\
\text { digunakan. }\end{array}$ \\
\hline
\end{tabular}

(Ibrahim dan Nur 2004)

Pengelolaan dosen dalam model kaitannya dengan pembelajaran pembelajaran PBI berbeda dengan peran dosen pada pembelajaran konvensional. menggunakan model pembelajaran berdasarkan masalah (Problem Based Menurut Sinambela (2008:83) terdapat Instruction) dalam hal ini meliputi: hal-hal yang diperhatikan dalam menjelaskan tujuan pembelajaran, 
menjelaskan logistik yang dibutuhkan, memotivasi siswa terlibat pada aktivitas pemecahan masalah yang dipilihnya. Selanjutnya, dalam mengorganisasikan siswa untuk belajar, guru berperan membantu siswa mendefinisikan dan mengorganisaikan belajar yang berhubungan dengan masalah tersebut.Dalam hal membimbing penyelidikan individual maupun kelompok peran guru dalam hal ini adalah mendorong siswa untuk mengumpulkan informasi yang sesuai, melaksanakan eksperimen, untuk mendapatkan penjelasan dan pemecahan masalah.

\section{Hasil Belajar}

Hasil belajar adalah proses perolehan atau hasil dari pada belajar ini ditandai dengan perubahan tingkah laku kearah dewasa melalui kemampuan kognitif (pengetahuan intelektual), bidang efektif (keterampilan bertindak atau berperilaku). Dalam kegiatan belajar mengajar tujuan yang ingin dicapai adalah hasil belajar.Hasil belajar tidak mudah dicapai oleh peserta didik tersebut tidak memperhatikan cara-cara dan faktor-faktor oleh mahasiswa tersebut tidak memperhatikan cara-cara dan faktor-faktor yang menunjang
keberhasilan.Menurut Slameto (2010: 2) hasil belajar adalah Suatu proses usaha yang dilakukan seseorang untuk memperoleh suatu perubahan tingkah laku yang baru secara keseluruhan sebagai hasil pengalamannya sendiri, sebagai perubahan dalam interaksi dengan lingkungan.

Proses pembelajaran, guru harus memiliki strategi agar mahasiswa dapat belajar secara efektif mengarah pada tujuan yang diharapkan sehingga mahasiswa dapat memperoleh prestasi yang gemilang. Salah satu prestasi mahasiswa dapat memperoleh nilai yang baik terutama dalam matakuliah Ekonomi Pembangunan.Hasil belajar mahasiswa terhadap matakuliah Ekonomi Pembangunan merupakan kemampuan mahasiswa untuk menangkap dan memahami konsep yang telah diberikan. Dalam hal ini akan terlihat dalam tes pelajaran yang disajikan pada mahasiswa sebagai akibat dari belajar maka hasil belajar tersebut berupa perubahan sifatnya permanen.

Ciri hasil belajar adalah perubahan, seseorang dikatakan sudah belajar apabila prilakunya menunjukkan perubahan, awalnya tidak tahu menjadi tahu, dari tidak bisa menjadi bisa dan 
tidak mampu menjadi mampu, dari tidak terampil menjadi terampil. Hasil belajar termasuk komponen pendidikan yang harus disesuaikan dengan tujuan pendidikan, karena hasil belajar diukur untuk mengetahui ketercapaian tujuan pendidikan melalui proses pembelajaran.

Hasil belajar dapat dicapai melalui proses belajar, ada beberapa faktor yang mempengaruhinya. Menurut Karwono (2012: 46) menyatakan faktor-faktor yang mempengaruhi hasil belajar terdiri dari dua faktor yaitu:

a. Faktor Intern yaitu fisiologis atau jasmaniah (kesehatan dan cacat tubuh), faktor psikologis (intelegensi, perhatian, minat, bakat, motivasi, emosi) dan faktor kelelahan.

b. Faktor Ekstern yaitu keluarga (cara orang tua mendidik, relasi antar anggota keluarga, perhatian orang tua, latar belakang kebudayaan), faktor sekolah (model pembelajaran, kurikulum, relasi guru dengan mahasiswa, relasi mahasiswa dengan mahasiswa), disiplin sekolah, alat pelajaran, waktu sekolah, standar pengajaran diatas ukuran, keadaan gedung, metode belajar, tugas rumah, faktor masyarakat (keadaan mahasiswa dalam masyarakat, mass media, teman bergaul, bentuk kehidupan masyarakat).

Menurut Sudjana (2003:22) hasil belajar adalah kemampuan yang dimiliki siswa setelah ia menerima pengalaman belajar. Kriteria hasil belajar suatu satuan nilai yang menjadi ukuran untuk menentukan tingkat keberhasilan terhadap hasil belajar dan kriteria ini biasanya didasarkan dengan standar atau ukuran yang ada.Dalam hasil ini hasil di kelompokkan menjadi dua kriteria tuntas dan belum tuntas. Hasil ini sesuai dengan penelitian belajar tuntas, tuntas apabila hasil yang dicapai siswa dalam tes adalah $65 \%$ atau lebih siswa dipandang menguasai bahan pelajaran yang bersangkutan dan siap mengikuti program selanjutnya. Sedangkan hasil yang dicapai kurang dari $65 \%$ dianggap belum tuntas.

\section{Kerangka Berpikir}

Kerangka berpikir adalah penjelasan sementara terhadap gejala yang menjadi objek permasalahan kita.Menurut Sekaran (Sugiyono, 2011:91) mengatakan bahwa "Kerangka pikir adalah model konseptual di identifikasi sebagai masalah yang penting“. Penulis menyimpulkan 
berdasarkan pendapat diatas bahwa penelitian variabel $\mathrm{X}=$ Model Problem yang dimaksud kerangka berpikir Based Instruction $(P B I)$, variabel $\mathrm{Y}=$ merupakan konsep dasar yang menurut hasil belajar Ekonomi Pembangunan. pertautan antara variabel-variabel dalam

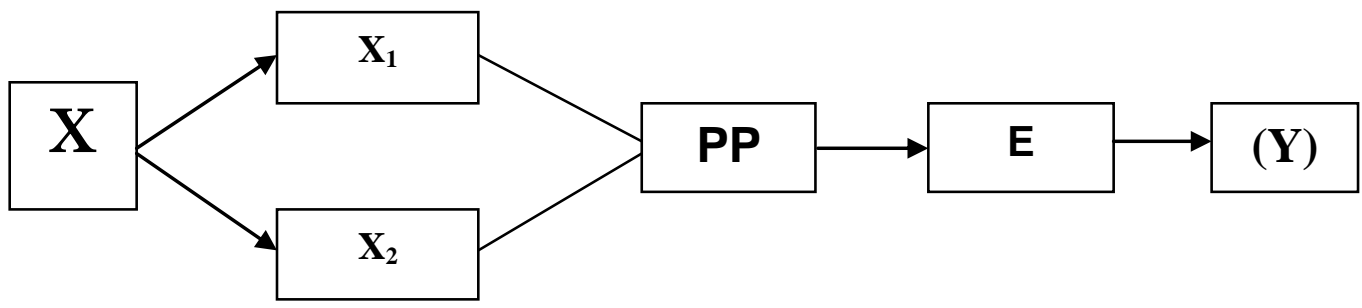

Gambar 2 Kerangka Berpikir

Keterangan :

X : Model Problem Based Instruction (PBI)

$\mathrm{X}_{1}$ : Penyampaian Kompetensi

$\mathrm{X}_{2}$ : Penyajian Masalah

PP: Poses Pembelajaran

E : Evaluasi

Y : Hasil belajar Ekonomi Pembangunan

\section{METODE}

Penelitian ini merupakan penelitian bersifat pengaruh, yang mengkaji pengaruh antara variabel bebas dari variabel terikat. Penelitian ini mencari bagaimana pengaruh penggunaan model Problem Based Instruction terhadap hasil belajar mmahasiswa pada mata kuliah Ekonomi pembangunan dengan menggunakan metode Eksperimen Designyaitu Pretest Posttest Control Group Design. Populasi dalam penelitian ini adalah seluruh mahasiswa semester 2 prodi Pendidikan Ukonomi di UM Metro yang berjumlah 55 orang yang terbagi menjadi 2 kelas, kelompok eksperimen yaitu pada kelas A dan kelompok kontrol pada kelas B.

Pelaksaan pretest baik kelas eksperimen maupun kelas kontrol dilakukan sebelum pelaksanaan proses pembelajaran dengan pretest dan dilaksanakan satu kali pertemuan. Setelah itu akan dilaksanakan proses pembelajaran dengan prestest proses pembelajaran baik pada kelas eksperimen maupun kelas kontrol dengan cara kelas eksperimen pembelajaran dengan menggunakan model Problem Based Instruction sedangkan metode diberikan perlakuan yang berbeda yakni dengan menggunakan metode konvensional yaitu 
ceramah disertai tanya jawab. Selanjutnya akan dilaksanakan posttest pada kelas eksperimen dan kelas kontrol untuk mengetahui hasil belajar dari proses pembelajaran.

Dalam penelitian ini pengaruh perlakuan terhadap hasil belajar dianalisis dengan menggunakan rumus regresi linier sederhana, dari data yang terkumpul kemudian dianalisis untuk menguji hipotesis yang telah dirumuskan sebelumnya. Dan dari hasil pengujian hipotesis yang telah dianalisis maka nantinya akan dapat dijadikan sebagai landasan untuk mengambil kesimpulan dalam penelitian. Adapun rancangan penelitian ini akan digambarkan sebagai berikut :

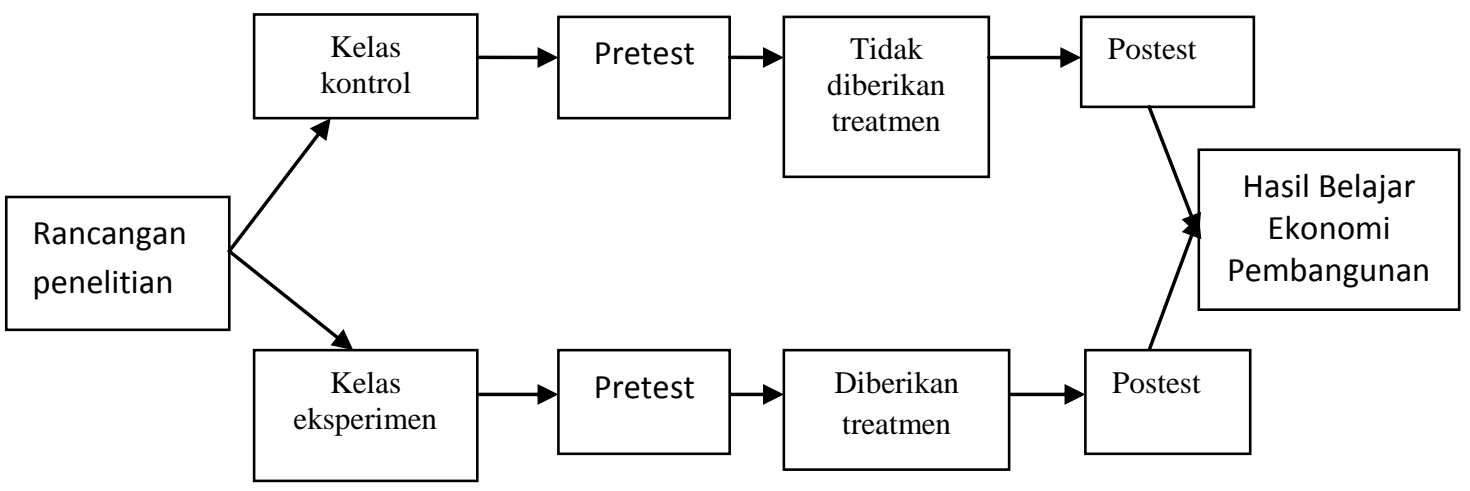

Gambar 2 Rancangan Penelitian

Variabel bebas berupa model yaitu $t_{\text {hitung }}$ lebih besar 2,06 dari $t_{\text {tabel }}$ pembelajaran PBI dan variabel terikat adalah hasil belajar mata kuliah ekonomi pembangunan.Teknik pengumpulan data yang digunakan dalam penelitian ini adalah dokumentasi, observasi, wawancara, eksperimen dan tes.Analisis data pada penelitian ini menggunakan analisis regresi linier sederhana. Sebelum dilakukan analisis data, maka dilakukan uji normalitas dan uji homogenitas

\section{HASIL DAN PEMBAHASAN}

Berdasarkan analisis perhitungan nilai $t_{\text {hitung }}$ dan $t_{\text {tabel }}$ diketahui bahwa $t_{\text {hitung }}>t_{\text {tabel }}$. Pada daftar signifikan 5\% yaitu 3,76>1,70 dan pada taraf signifikan $1 \%$ yaitu $3,76>$ 2,47 yaitu $t_{\text {hitung }}$ lebih besar 1,29 dari $t_{\text {tabel }}$. Dengan demikian $\mathrm{H}_{\mathrm{O}}$ diterima yang berarti bahwa penerapan model Problem Based Instruction pada matakuliah Ekonomi Pembangunan dapat meningkatkan hasil belajar mahasiswa di UM Metro.

Selanjutnya nilai-nilai dari hasil belajar mahasiswa pada matakuliah Ekonomi pembangunan dari evaluasi uji Pretest ataupun Posttest, setelah diberikan treatment Problem Based Instruction dapat dilihat pada tabel berikut: 
Tabel 2. Presentase Hasil Belajar Mahasiswa Pada Matakuliah EkonomPembangunan di UM Metro

\begin{tabular}{|c|c|c|c|c|c|c|}
\hline \multirow[b]{2}{*}{ No } & \multirow{2}{*}{$\begin{array}{r}\text { In } \\
\text { terval } \\
\text { Nilai }\end{array}$} & \multirow{2}{*}{$\begin{array}{l}\text { Kate } \\
\text { gori }\end{array}$} & \multicolumn{2}{|c|}{$\begin{array}{c}\text { Evaluasi uji } \\
\text { Pretest }\end{array}$} & \multicolumn{2}{|c|}{$\begin{array}{c}\text { Evaluasi Uji } \\
\text { Posttest } \\
\end{array}$} \\
\hline & & & $\begin{array}{r}\text { Jumlah } \\
\text { Mahasiswa }\end{array}$ & $\begin{array}{l}\text { Presentas } \\
\text { e }\end{array}$ & $\begin{array}{r}\text { Jumlah } \\
\text { Mahasiswa }\end{array}$ & $\begin{array}{l}\text { Presen } \\
\text { tase }\end{array}$ \\
\hline 1 & $\geq 70$ & Tuntas & 8 & 28,5 & 24 & 80 \\
\hline 2 & $<70$ & $\begin{array}{l}\text { Belum } \\
\text { Tuntas }\end{array}$ & 22 & 71,5 & 6 & 20 \\
\hline \multicolumn{3}{|c|}{ Jumlah } & 30 & 100 & 30 & 100 \\
\hline
\end{tabular}

Berdasarkan tabel diatas dapat diketahui bahwa pada tahap evaluasi uji pretest, bahwa mahasiswa yang mencapai tuntas belajar hanya 28,5\% ( 8 mahasiswa), sedangkan mahasiswa yang belum mencapai tuntas belajar adalah $71,5 \%$ (22 mahasiswa), dengan demikian dapat di temukan bahwa jumlah mahasiswa yang belum tuntas belajar atau belum mencapai standar ketuntasan yang telah ditetapkan masih banyak yaitu $71,5 \%$ atau 22 mahasiswa dari total keseluruhan mahasiswa sebanyak 30 mahasiswa dan tabel di atas dapat menunjukkan juga bahwa pada tahap evaluasi uji posttest, setelah mahasiswa mendapatkan treatment atau perlakuan Problem Based Instruction yang mencapai tuntas belajar berjumlah 80\% (24 mahasiswa), sedangkan mahasiswa yang belum mencapai tuntas belajar berjumlah 20\% (6 mahasiswa), dari total keseluruhan mahasiswa sebanyak 30 mahasiswa.
Di dalam penelitian, setelah mahasiswa mendapatkan treatment atau perlakuan Problem Based Instruction hasil belajar matakuliah Ekonomi Pembangunan mengalami peningkatan dilihat dari perbandingan pada evaluasi pretest dan evaluasi posttest, yaitu mahasiswa yang mencapai kriteria ketuntasan minimal pada evaluasi pretest adalah $28,5 \%$ atau 8 mahasiswa dari total keseluruhan mahasiswa 30 mahasiswa, sedangkan mahasiswa yang mencapai kriteria ketuntasan minimal pada evaluasi posttest adalah $80 \%$ atau 24 mahasiswa, dari total keseluruhan mahasiswa sebanyak 30 mahasiswa. Secara keseluruhan bahwa setelah mahasiswa mendapatkan treatment, perlakuan Problem Based Instruction hasil belajar matakuliah Ekonomi Pembangunan mengalami peningkatan, karena penggunaan Model Problem Based Instruction ini menekankan mahasiswa lebih aktif dalam proses pembelajaran 


\section{KESIMPULAN}

Berdasarkan penelitian dan analisis data yang telah dilakukan oleh peneliti, maka dapat diambil kesimpulan bahwa analisis perhitungan nilai $t_{\text {hitung }}$ dan $t_{\text {tabel }}$ diketahui bahwa $t_{\text {hitung }}>t_{\text {tabel}}$. Pada daftar signifikan $5 \%$ yaitu $3,76>1,70$ yaitu $t_{\text {hitung }}$ lebih besar 2,06 dari $t_{\text {tabel }}$ dan pada taraf signifikan $1 \%$ yaitu $3,76>2,47$ yaitu $t_{\text {hitung }}$ lebih besar 1,29 dari $t_{\text {tabel }}$.

Hipotesis dapat dikatakan diterima karena dilihat dari hasil belajar yang mengalami perubahan kearah yang positif dari $28,5 \%$ atau 8 mahasiswa tuntas setelah dilakukan treatmen menjadi $80 \%$ atau 24 mahasiswa, dengan kata lain hasil belajar dari proses pembelajaran menggunakan Problem Based Instruction mengalami peningkatan.

Sehingga dari hasil kriteria uji tersebut maka dapat disimpulkan bahwa penerapan model Problem Based Instruction pada matakuliah Ekonomi Pembangunan dapat meningkatkan hasil belajar mahasiswa di UM Metro.

Berdasarkan kesimpulan yang dipapar diatas, maka penulis mencoba mengemukakan saran-saran guna meningkatkan hasil belajar sebagai berikut:

1. Dalam rangka meningkatkan hasil belajar, penulis merekomendasikan model pembelajaran ini sebagai cara alternatif untuk bisa diterapkan di perguruan tinggi, Alternatif model pembelajaran yang penulis sarankan yaitu model Problem Based Instruction karena model ini dapat meningkatkan pemahaman serta proses berpikir kritis mahasiswa.

2. Penerapan model Problem Based Instruction membutuhkan waktu yang cukup banyak dalam proses pembelajaran agar mahasiswa mempunyai kesempatan yang luas untuk menemukan, memecahkan masalah dan membangun konsep melalui pengamatan dan diskusi, oleh karena itu dosen harus merencanakan dan mengatur waktu dengan baik.

\section{DAFTAR RUJUKAN}

Ibrahim, M dan M. Nur. 2004. Pengajaran Berdasarkan Masalah. Surabaya: Pusat Sains dan Matematika Sekolah, Program Pascasarjana UNESA, University Press.

Karwono, 2012.Belajar dan Pembelajaran Serta Pemanfaat Sumber belajar. Jakarta: PT Raja Grafindo Persada

Mulyasa E. 2006. Kurikulum yang Disempurnakan. Bandung: PT Remaja Rosdakarya

Nasution, P. 2008. Penerapan Model Problem Based Instruction (Problem Based Instruction) dalam Pembelajaran Matematika di SMU. Dinamika Vol. VI No. 1, 33

Nurhadi. 2004.Kurikulum 2004 (pertanyaan dan jawaban).Jakarta: Grasindo. 
Sinambela. 2008. Faktor-Faktor Penentu Keefektifan Pembelajaran Dalam Model Pembeljaran Pembelajaran Berdasarkan Masalah (Problem Based Instruction) dalam jurnal.pdii.lipi.go.id diakses tanggal 15 juli 2010

Slameto. 2010. Belajar dan Faktor-Faktor yang Mempengaruhinya. Jakarta: Rineka Cipta.

Sudjana, N. 2003.Penilaian Proses Belajar Mengajar. Bandung: PT. Remaja Rosdakarya

Sugiyono, 2011.Metode Penelitian Kuantitatif Kualitatif Dan $R \& D$. Bandung: Alfabeta.

Suparmanto,A.2004.Penerapan Metode Projek dalam setting model pembelajaran Berdasar Masalah untuk mengajar biologi di SMA.Suplemen DiajukanKepada Ketua Program Studi pendidikan sains Program PascasarjanaUniversitas Negeri Surabaya sebagai Arsip. Surabaya: Program Studipendidikan sains, Program pascasarjana UNESA

Trianto. 2007. Model-Model Pembelajaran Inovatif Berorientasi Konstruktivistik. Jakarta: Prestasi Pustaka Publisher. 
ISSN: 2442-4994 Vol.4. NNo.1 (2016) 35-45 